\title{
IJTARP
}

International Journal of Transactional Analysis

\section{Interpretative Phenomenological Analysis of Experiences of Four Individuals Reporting Exposure to Workplace Bullying in the UK}

\section{(C) 2018 Mary O’Neill \& Denise Borland}

\begin{abstract}
Suggesting that bullying is a toxic dynamic that is widespread in the modern workplace, the authors review general, research and transactional analysis literature on the topic and conclude that there is little documented about the adverse interaction on the individual. They go on to describe their conduct of an Interpretative Phenomenological Analysis (IPA) of the experiences of four individuals who self-identified and were also operationally identified using an amended version of the Negative Acts Questionnaire (NAQ-R) as being bullied by a manager within their organisation. A general questionnaire about experiences of bullying was also used, followed by interviews. Transcripts were analysed, and three themes and seven sub-themes were identified. Findings suggest that the participants experienced feelings of anger and worthlessness, but these feelings were muted and diminished as evidenced by participants' language and narrative styles. This is interpreted as them discounting their experience and the resulting impact on their health. Participants were found to be perceiving their manager as critical and blaming, and to have lost trust in them because of alleged breaches of boundaries. The participants also perceived the organisation negatively if they failed to support the participant; this was regarded as an endorsement of the negative behaviours. The resulting themes are analysed using several TA concepts, including discounting, life positions, psychological games, drivers, miniscript and script.
\end{abstract}

\section{Key words}

Workplace bullying, transactional analysis, interpretative phenomenological analysis, NAQ-R, miniscript, discounting, drivers, psychological games, managers, leadership, organisation

\section{Introduction}

This is a qualitative research study using Interpretative Phenomenological Analysis (IPA) into the experiences of individuals involved in a hostile interaction with a manager in their place of employment (organisation). It is a preliminary study aimed at identifying what it is like to be bullied and interpreting those experiences using transactional analysis (TA) concepts and theories. There is little research data that specifically identifies the feelings and thoughts of the targets of bullying (Lutgen-Sandvik, 2013); what this study aims to document, through the words of the individuals, is the psychological damage that bullying can do. Our themes illustrate how bullying leaves people feeling angry and worthless, they berate themselves for not acting sooner and discount the impact on their health and continue to go to work. The bully is perceived as critical and blaming with scant regard for personal boundaries and the organisation that fails to intercede and resolve the issue is viewed in the same negative light as the manager.

The whole process seems to function with a high level of discounting (Schiff \& Contributors, 1975), so the initial conclusion would be to assume that this would be a psychological game (Berne, 1964), although we did not observe such dynamics within the transcripts. It was of interest to us to stay with the focus on the impact on the participants, particularly the prevalence of discounting and the response by the participants to their situation from within script (Steiner, 1974) as observed through the miniscript sequence (Kahler \& Capers, 1974).

The authors work in the fields of counselling and psychotherapy therefore the data presentation, the interpretations and conclusions reflect their backgrounds and experiences. Mary O'Neill is a TA 
counsellor (MSc) in an occupational health setting and sees clients who experience a stressful work environment. Counselling is offered on a short-term basis (six sessions) and many of the clients reported experiencing unacceptable behaviour by a manager or a colleague. This led to an interest in the issue of workplace bullying with a view to developing a TA counselling approach that would help clients dealing with this issue.

Denise Borland is a TA psychotherapist (Certified Transactional Analyst (CTA), MSc) and her PhD is in Vocal Performance Psychology (of professional singers). As a psychotherapist and psychological education coach specialising in vocal performance within the music Industry, she has extensive personal experience of the power dynamics, both in training and professional settings. Vocal performance can often falter when people have experienced bullying and their words and self are not valued or validated. As she has many coaching clients in this area this seemed a good match for a research study collaboration.

\section{Literature Review}

The phenomenon of workplace bullying is a blight on the modern workplace, affecting one in three workers in the UK (Trades Union Congress - TUC website 2015). Bullying terrorises, belittles and dehumanises the individual and causes psychological damage (Tracy, Lutgen-Sandvik \& Alberts, 2006). It is also unproductive, expensive and time consuming for the organisation (Glendinning, 2001). The Advisory, Conciliation and Arbitration Service (ACAS, 2015) define bullying as: “...offensive, intimidating, malicious or insulting behaviour, an abuse or misuse of power through means that undermine, humiliate, denigrate or injure the recipient”. (p.1)

There is a large volume of quantitative analysis on the process of bullying, focussing on the nature of personality, antecedents, and organisational responses (reviewed in Branch, Ramsay \& Barker, 2012; Einarsen, Hoel, Zapf \& Cooper, 2011). There are also smaller, qualitative studies of workplace bullying again focusing on behavioural interactions (Farrell, Keenan \& Knibbs, 2014) and antecedents of bullying (Lutgen-Sandvik, 2013). There is very little information about what it feels like to be bullied and what individuals feel and think about themselves, the perpetrators and the organisation (Tracy et al., 2006). There are studies that have used metaphor analysis to define how targets experience being bullied (Tracy et al., 2006), interview analyses (Keashly, 2001) and Social Exchange Theory (SET) (Parzefall and Salin, 2010) to describe the experiences of targets.

A further study of the literature suggests four criteria that are required to define bullying:
1. The acts and behaviours are prolonged and sustained; specifically occurring at least weekly over a period of approximately 6 months (Einarsen, Hoel \& Notelaars, 2009);

2. The target perceives the behaviour as having a negative impact on their performance or health. (Matthiesen \& Einarsen, 2004);

3. There is a power differential between perpetrator and target where the target is put in an inferior position (Matthiesen \& Einarsen, 2007);

4. A further condition to bullying includes escalation in severity over time, (Einarsen et al., 2009; Soares, 2012).

\section{Bullying Behaviours}

The negative treatment referred to in the above definitions are again subject to interpretation. However, Einarsen \& Raknes (1997) have distilled these negative behaviours into three distinct categories; those affecting the target's work, those directed at the person, and acts of intimidation.

Work may be affected by being given an excessive workload or given work beneath the target's capabilities, acts of misinformation or omission that prevent the target doing their job effectively, and excessive criticism of their work.

Bullying behaviours that impact the person will include being ignored, being spoken over and having opinions disregarded. There are also provocative behaviours which include being ridiculed, insulted and humiliated and being the target of jokes and criticism. Finally, there are those acts which are also directly threatening and intimidating, such as verbal and physical assaults to the person or their property (Einarsen et al., 2009).

Some bullying definitions mention the occurrence of many small incidents that might appear inconsequential, but over time the accumulative impact of these negative acts has a destructive impact on the target's health (Keashly 2001; Hutchison, Wilkes, Vickers \& Jackson, 2010; Soares, 2012).

\section{Identifying Bullying for Research Purposes}

When it comes to defining bullying for research purposes there are two possible methods; operationally defined bullying and self-defined bullying. The operational method identifies bullying behaviours using a questionnaire, the most widely used being the revised Negative Acts Questionnaire (NAQ-R) (Einarsen et al., 2009) which is described in detail in the methodology section (see Appendix 1). This method accounts for frequency of behaviours but excludes unique experiences and does not account for severity of impact, e.g. being insulted could cover a spectrum of cruel jibes from mild to vicious. It also fails 
to account for the fact that some individuals may not experience certain behaviours as bullying, e.g. a police officer who is subjected to insults and assaults as 'part of the job' (Nielsen, Notelaars \& Einarsen, 2011).

Self-defined bullying presents the individual with a discrete definition of bullying and asks them to agree or disagree with the definition. This method is useful in that it is simple to administer but risks subjective bias. Individuals are more likely to self-identify if they have negative affect and others may not wish to define themselves as being bullied as it would provoke feelings of victimisation (Hogh, Hoel \& Carneiro, 2011).

The term 'target' of bullying is often applied via the operational method to indicate the individual is the systematic focus of negative acts, whereas the term 'victim' of bullying is sometimes associated with the self-defined method.

When identifying bullying for research purposes, the recommendation is to use both methods; selfdefinition allows the individual to identify as being bullied and the operational use of the NAQ-R allows identification of behaviours and frequency (Nielsen et al., 2011).

Workplace bullying has a serious impact on physical and mental health; it is not uncommon for those exposed to bullying to experience depression and anxiety including panic attacks (Keashly \& Harvey, 2006). These individuals may mention a perceived loss of confidence in themselves and their ability to do their job (Vartia, 2001; Hogh et al., 2011).

There is also further evidence that prolonged exposure to bullying and intense bullying will result in symptoms that correspond to Post Traumatic Stress Disorder (PTSD), specifically hyperarousal and perception of the world as 'not safe' (Hoel, Faragher \& Cooper, 2004; Tehrani, 2004; Vie, Glasø \& Einarsen, 2011).

Personality has little to do with being a target of bullying; while some research suggests that introversion and high levels of neuroticism are more likely to be associated with the targets of bullying (Glasø, Matthiessen, Nielsen \& Eiarsen, 2007), there is not sufficient evidence to confirm this and it has been argued since the early days of research that it cannot be proven that the bullying itself did not affect levels of neuroticism and introversion in the first place (Leymann, 1996). Nielsen, Matthiessen \& Einarsen (2008) stated that even for the most optimistic and confident of individuals, the experience of being severely bullied was sufficient to traumatise as they were unused to such ill-treatment and it created a strong cognitive dissonance between their situation and their previously positive view of the employer.
Workplace Bullying and the Role of Organisations Where bullying exists in an organisation, the impact may include increased absenteeism, lost productivity and reduced creativity (Glendinning, 2001). When employees experience bullying, they might be forced to leave their job resulting in a loss of knowledge and expertise from the organisation. Furthermore, there may be a financial cost in retraining and possible industrial tribunals and litigation (Lutgen-Sandvik, 2013; Samnani \& Singh, 2012; Wheeler, Halbesleben \& Shanine, 2010).

Bullying within an organisation is often regarded as an organisational problem requiring an organisational response (ACAS, 2015) and must be tackled at the cultural level of the organisation and the management structures therein (Vartia \& Tehrani, 2012). Organisations and their employees are bound by both an explicit (business) contract and an implicit psychological contract (Cornell, de Graaf, Newton \& Thunnissen, 2016). With the latter, the employee trusts the employer to deliver favourable work conditions, and, in return they offer a good performance. Bullying can breach this contract where the employee sees the employer as reneging on these implied contractual responsibilities, (Parzefall \& Salin, 2010).

One of the major criteria for bullying is a power differential (Einarsen et al., 2009), where organisations create unhealthy power imbalances through poor leadership, deficiencies in work design and generating low morale (Harvey, Treadway, Heames \& Duke, 2009). Krausz (1986) describes power as the "capacity of one person to influence or control the behaviour of others" (p.85). According to her, rewarding, coercion and position are classic types of power within an organisation, e.g. having the power to hire and fire, to dictate policy and to reward with promotion and remuneration. Managers who operate with a Criticising mode of leadership (Mountain \& Davidson, 2011) i.e. I'm OK, You're not OK, might use coercion, reward and position in a way that invites an I'm not OK life position from the employee and leads to over-adaptation and game playing.

Bullying will occur in organisations when the culture of that organisation condones, models or rewards it (Lutgen-Sandvik, 2013) and if an organisation fails to take responsibility for its hostile culture, it leads to a loss of loyalty amongst employees and creates a mistrust in the organisation and its policies and procedures (Mountain \& Davidson, 2011).

Transactional Analysis and Workplace Bullying Transactional Analysis (TA) has much to offer in the examination of human behaviour and organisational culture. The concepts of TA are useful for describing the individual's internal experience and their interact- 
ions with others at a personal and an organisational level.

Bogren (2008) writes about school bullying and describes the process as a game where the children establish a power play between each other with the bully as Persecutor and the target as Victim. Mountain \& Davidson (2011) describe bullying behaviours as having roots in childhood where a child learns to bully as a way of protecting against the Victim position; the individual is fearful but defends against the fear with a substitute feeling of anger and an aggressive style of behaviour.

Games are played out of awareness, to structure time and acquire strokes (normally negative) (Berne, 1964). It might be considered that workplace bullying has the hallmarks of a game and the degree of escalation suggests that this game is played at the $2^{\text {nd }}$ and ultimately $3^{\text {rd }}$ degree level, where ill health, litigation and even suicide have been the outcome (Keashly, 2001; Soares, 2012; Zapf \& Einarsen, 2011). The bully would be perceived to be in the Persecutor role with the target in the Victim role and each role will involve discounts. These discounts may be a mechanism of defence in relationship with others which may reinforce the script beliefs of the players (Cornell et al., 2016; Mountain \& Davidson, 2011).

\section{Study Objectives}

The aim of this study was to document the experiences of people who are subjected to workplace bullying and to conceptualise their experiences using TA. It was proposed to do a small scale qualitative study using Interpretative Phenomenological Analysis (IPA) (McLeod, 2011; Smith, Flowers \& Larkin, 2009). Participants would be able to describe their experiences focusing on their feelings and beliefs so that a better understanding of the impact of bullying on individuals would be achieved. By focusing on the emotional and cognitive processes of the participants, the emerging themes would be a reflective account of what it is like to be bullied and would be analysed and interpreted using the concepts of TA, which would hopefully give the TA therapist an understanding of this phenomenon that they could use when working with clients who describe being bullied.

In using IPA, we describe the shared experiences and perceptions of four individuals and interpret their experiences using the concepts of TA. We did not set out to analyse the transcripts with a specific TA concept in mind but to let the accounts speak for themselves.

\section{Methodology}

IPA invites the individual to talk about and reflect on their experiences and how they have made meaning of their experience. This in turn is interpreted by the researcher creating a double hermeneutic (Macleod 2011; Pietkiewicz \& Smith, 2012; Smith et al., 2009).

Sample sizes are invariably small, allowing for an indepth analysis of the experience. It is the in-depth analysis of each transcript rather than a broad summary across many individuals that is one of the main strengths of IPA (Hefferon \& Gil-Rodriguez, 2017; Macleod, 2011).

The following questions were asked of the participants, aimed at prompting the feelings and beliefs that arose from their experience.

1. How did it all start? (Prompt: Was there a triggering incident?)

2. On a typical day describe the sort of incidents that would occur? (Prompt: Describe a typical incident.)

3. What was your experience when you interacted with the perpetrator e.g.?

a. How did you feel when you interacted with them?

b. What did you believe about yourself at that time?

4. Describe the perpetrator(s).

5. How would you describe the role of your organisation in the situations described?

6. Was the situation resolved and if so, were you satisfied with the resolution?

The questions were intended to be as open as possible to invite the participants to discuss their experiences and to see what issues arose. Bullying often begins with a triggering incident such as a change or the arrival of a new manager (Vartia \& Tehrani, 2012). By enquiring about a typical day it was intended to get the individual to discuss specific acts. Questions 3 and 4 were intended to elicit information about how they felt about themselves and the perpetrator and Questions 5 and 6 were intended to explore feelings towards the organisation and how the situation ended.

Interviews were semi structured in that all participants were asked the 6 questions and invited to speak at length. The researcher could ask for further information at relevant points and seek clarification as needed. The interview sessions were taken separately and before a regular session, giving space to further discuss anything that the interview may have brought up for them. There was discussion and planning ahead of the sessions to prepare with clients who were already very capable of working with their autonomic nervous systems (Rothschild, 2000) and returning to Adult (Berne, 1961) to avoid being overwhelmed. 
Afterwards, verbatim transcripts were produced and read through multiple times. Each transcript was analysed individually; specific words and phrases were highlighted including the use of metaphor and euphemisms. Attention was also paid to the coherence of narrative, hesitation and pausing. They were analysed for common themes; each researcher did their own analyses and formulated possible themes, then met together to discuss and agree the overall themes.

\section{Study participants}

Recruitment was done through a call for participants in the TA and Counselling communities of the authors. One participant was recruited by a call for participants on a professional Facebook page which had no personal links to the researchers and was used to post articles related to mental health, to promote TA counselling, and announce events such as seminars and workshops on mental wellbeing. The other three participants were recruited through one of the researchers' private practice. Names have been changed to protect anonymity. Participant demographics are shown in Table 1.

All the participants worked with a line manager in teams which were part of a larger organisation. Adam worked for a large private sector organisation (more than 1000 employees). Diana was based in a hospital in the public sector (more than 1000 employees). Chloe worked for a voluntary sector organisation (1001000 employees). Becky worked for a small, private sector organisation of less than 100. Participants had to deal with either senior managers or with HR regarding their situations.

The participant (Adam) was not known to the researchers and received coaching from an unrelated professional and had worked through his experience.

The material, though provoking, was current for Becky only; it was already placed in the past for the others. Chloe and Diana reported in subsequent sessions that the reflective space was useful for furthering understanding and making meaning (Levine, 1997, 2005) of their experience.

Instruments of Assessment

Before interview, it was necessary to identify participants who fitted the criteria for workplace bullying. This was operationally defined using an adapted NAQ-R that had been approved for use by Einarsen (2017), as shown as Appendix 1. Completed before interview, the questionnaire lists 22 negative acts relating to the workplace without using the term 'bullying'. It incorporates personal attacks, workplace incidents and physical intimidation; the intensity of the bullying is characterised by identifying frequency levels of workplace incidents which are also allocated a score (Never $=1$, Now and then $=2$, Monthly $=3$,
Weekly = 4 and Daily =5). Notelaers \& Einarsen (2013) published cut-off scores for the questionnaire to assist with identifying bullying. Scored by totalling the frequency of each event experienced, a score of 32 or below indicates no bullying; 33 to 44 indicates that some bullying is going on and that it may be in the early stages of bullying; 45 or more would indicate severe workplace bullying. To qualify for the study, participants had to score 45 or more in the NAQ-R and the results are shown in Table 2.

For self- definition, participants were asked to complete a second questionnaire (Appendix 2). This questionnaire included the following definition of workplace bullying taken verbatim from Hoel et al. (2004): "a situation where one or several individuals, persistently over a period, perceive themselves to be on the receiving end of negative actions from one or several persons, in a situation where the target of bullying has difficulty in defending him or herself against these actions" (p.368).

The participants were asked to state if they believed that definition applied to their situation, thereby confirming the self-identified requirement. There were further questions about organisation size, duration of bullying and whether they were still working for the organisation, as summarised in Table 2.

\section{Ethical Considerations}

A detailed permission request was presented to the participants, outlining their role and explaining the nature of the study. Interviews were arranged with the participants and time was given for them to discuss and question the nature of the interviews. Confidentiality and anonymity were assured for both participants and their respective managers and organisations. The names of organisations were not requested, and any mention of managers' names has been changed (normally just first names were mentioned).

Participants were encouraged to gain support through friends and family or from a counsellor. Three out of four were already seeing one of the researchers as a coach/psychotherapist. Time was spent with the fourth individual to discuss the implications of the project before he agreed to be interviewed by one of the researchers. The interviews with the three remaining participants were carried out by the researcher before their counselling session and these three participants were able to reflect with the counsellor in this space on the impact of the interview.

It was emphasised that the participants could withdraw from the study at any stage in the proceedings; all were happy to proceed. Permission was gained for recording and the transcripts of the sessions were sent to the participants to check that they were satisfied with the accuracy. Participants were not asked to 
review the themes as there was some concern that this may have led to rupture within the therapeutic relationship and may have further complicated the analyses. The interviews were followed up with further coaching sessions and the subject was returned to in subsequent sessions to further reflect and offer containment for the participants.

\begin{tabular}{|c|c|c|c|c|}
\hline Participant & $\begin{array}{c}\text { Gender of } \\
\text { Participant }\end{array}$ & Age & Job Description & Organisation \\
\hline Adam & Male & 51 & IT professional & $\begin{array}{r}\text { Large Private Sector Organisation } \\
(>1000 \text { employees })\end{array}$ \\
\hline Becky & Female & 27 & Childcare professional & $\begin{array}{r}\text { Small Private Sector Organisation } \\
(>100 \text { employees })\end{array}$ \\
\hline Chloe & Female & 29 & Personal Assistant & $\begin{array}{r}\text { Medium sized Voluntary Sector } \\
\text { Organisation }\end{array}$ \\
\hline Diana & Female & 41 & Healthcare professional & $\begin{array}{r}\text { Large Public-Sector Organisation } \\
\text { ( } 1000 \text { employees })\end{array}$ \\
\hline
\end{tabular}

Table 1: Participant Demographics

\begin{tabular}{|c|c|c|c|c|}
\hline Participant & $\begin{array}{c}\text { Gender of } \\
\text { Perpetrator } \\
\text { (manager) }\end{array}$ & $\begin{array}{c}\text { Duration of Bullying } \\
\text { (months) }\end{array}$ & $\begin{array}{c}\text { Still with the organisation } \\
\text { at time of interview }\end{array}$ & NAQ Score \\
\hline Adam & Male & 9 & No & 49 \\
\hline Becky & Female & 12 & No & 49 \\
\hline Chloe & Female & 33 & No & 54 \\
\hline Diana & Female & 96 & & 54 \\
\hline
\end{tabular}

Table 2: Summary of participants' experiences of being bullied.

\begin{tabular}{|l|l|l|}
\hline \multirow{4}{*}{ Theme 1 } & \multirow{2}{*}{$\begin{array}{l}\text { The impact of bullying on the } \\
\text { individual }\end{array}$} & Impact on mental health and physical health \\
\cline { 3 - 3 } & & Individuals experience feelings of worthlessness \\
\cline { 3 - 3 } & & Individuals experience anger \\
\cline { 3 - 3 } Theme 2 & $\begin{array}{l}\text { The perceived role of the } \\
\text { manager }\end{array}$ & Breached boundaries leading to loss of trust \\
\cline { 3 - 3 } & & Blame and Criticism \\
\cline { 3 - 3 } & & Withholding \\
\hline Theme 3 & The perceived role of the organisation \\
\hline
\end{tabular}

Table 3: Themes and Sub- Themes 


\section{Results}

We identified within the narratives reference to material that would be explained by concepts such as drivers and miniscript (Kahler \& Capers, 1974), and to a lesser extent stroke economy (McKenna, 1974), OK Corral (Ernst, 1971) and the drama triangle (Karpman, 1968). We also identified significant use of discounting and passive behaviours (Schiff \& Schiff, 1971). The data will be discussed using these concepts, but the reader may find other TA concepts that would explain the interactions, reflecting the flexibility and power of TA to analyse this subject.

All the participants self-identified as being bullied and each person was bullied by a manager of the same gender. All scored above 45 in the NAQ-R. Becky scored the highest at 84 due to a higher number of negative acts experienced on a daily/ weekly basis (16/22). Adam, Chloe and Diana experienced fewer negative acts on a weekly/daily basis (5/22, 6/22 and $7 / 22$ respectively). Bullying can also be defined as two or more negative acts on a daily or weekly basis over a minimum of six months (Einarsen et al., 2009) and all the participants were above the threshold by this criterion.

The triggers for the bullying varied across the participants:

- Adam suggested that it was the result of change in the organisation and the ensuing pressures put on staff caused the increase in bullying behaviours.

- Becky suggested that the bullying began when the new manager arrived in the team and twelve people had subsequently left the team in the past twelve months.

- Chloe said that the bullying began almost immediately, and she later discovered that the manager already had a reputation of being difficult to work with as previous people in her position seemed to last only six months.

- For Diana the behaviours began when she arrived in the organisation and seemed to be a common work practice within the team.

Themes identified

Table 3 show the three main themes that were identified: the impact on the individual, with four subthemes; the perceived role of the manager, with three sub-themes; and the perceived role of the organisation.

Each of these themes is addressed below using quotes of the participants.

Theme 1: The impact on the individual

This theme addressed how the participants experienced themselves; specifically the impact on their mental and physical health, their feelings of anger and sense of worthlessness. The assertion that they should have acted sooner in reporting to the organisation was the result of their responses to the final question regarding a resolution to their situation.

Theme 1: The impact on the individual: SubTheme 1: Impact on mental and physical health All 4 participants stated that they felt vulnerable and insecure when dealing with their manager (and sometimes colleagues).

"I think it affected my kind of getting up and going to work and em... I think it probably affected my... my general mood really... em... so... em I was probably in a way the least aware of the issue but my wife, she noticed a big difference in the way I was behaving" [Adam]

"I'm stressed on a daily basis; I'm nervous every single day I go into work I'm even nervous right now after doing a ten-hour shift and I'm still think about it. I'm thinking l've got to back tomorrow you know... I'm always nervous about it you know, so it... it never leaves my system" [Becky]

“... so, I stuck with it even though I was really miserable and having panic attacks every single day on the way to work so that's why I had to end up taking the anti-depressant or anti-anxiety medication" [Chloe]

“... yeah it was definitely rejection but couldn't understand the rejection then what I did was obviously start to turn it in on myself"

“... I lost an awful lot of weight in that time and em... it actually wasn't until I went down to $51 / 2$ stone that I think management got involved and everybody backed off" [Diana]

Theme 1: The impact on the individual: Sub-

Theme 2: Feelings of worthlessness

This theme was noted in that all participants made mention of feeling unimportant and irrelevant to their workplace situation either in the relationship with the manager and/or the organisation. The response came when asked what they believed about themselves when they interacted with the perpetrator (Q3 b).

Becky and Diana were the most explicit:

“... I believe I'm worthless and that I can't do anything right even though I'm trying and I know logically I am trying and working very hard but she makes me feel like I might as well not be there" [Becky]

"I felt that I was... I wasn't worthy and that I wasn't good enough... that em... and I was always having to prove myself"

“... I'm thinking maybe that's what they wanted in a way. That I was always... that I was always under the foot - if that makes sense" 
"I was used and I was never part of the team and em... I feel that I was basically like nobody." [Diana]

\section{“... I didn't feel valued” [Chloe]}

"... it kind of felt like she was the headmistress and she had prefects (laughs) I certainly wasn't one... either of those (laughs) I was definitely one of the... seen as probably the lowest or the lower end of the... I felt I was on the lowest end of the food chain" [Chloe]

Adam didn't explicitly state he felt worthless but rather that the effort he put into the job was unappreciated,

"I didn't get to... get to feel I had become an incompetent worker but I did feel under pressure and... and... Crushed was a better word really... I felt there was no end really... I couldn't see a way out with what was going on. It was like being in a tunnel you know, I couldn't see a way out." [Adam]

"I felt it couldn't continue as it was... Something had to give really, and when every effort you put in wasn't really appreciated... I felt I was being sucked dry." [Adam]

Theme 1: The impact on the individual: Sub-

Theme 3: Individuals experience anger

The participants described feeling angry with the manager and with the organisation.

“... I still feel a fair bit of anger about it... I think he was and is somewhat out of his depth and... em... and he was just following orders from above really but I think the way he kind of treated people... is vile really um... Yes, a lot anger really... about him really." [Adam]

“... I'm just kind of wanting to tell her to stop speaking to me in ... that way and... I that don't appreciate it... Em... I get... I get really annoyed at it yeah if I'm perfectly honest I think." [Becky]

“... I lost my temper I can't remember exactly what I said but I just said I wasn't going to have her standing over me and one of the others... said that the way l'd spoken to $[B]$ was appalling but she hadn't seen the catalogue of... yeah... of items on the run up to it." [Chloe]

"I didn't feel happy... [I felt]... Frustrated... Em (pause) frustrated and angry because... I just felt they were... Prolonging (laugh)... prolonging kind of my training..." [Diana]

Theme 1: The impact on the individual: Sub-

Theme 4: Nipping it in the Bud

All four participants stated they had let things go on too long and in hindsight they should have acted sooner. This may have been in the form of making a formal complaint or leaving the job.

“... maybe with hindsight... It was quite a big decision and to kind of put in a complaint about the manager and the longer it goes on the more difficult it becomes in term of you own energy level... I think to do that probably I needed to do that quite early on" [Adam]

“... I think for anyone experiencing bullying you just need to go to your manager and get it kind of just... nip it in the bud as soon as possible and just don't suffer and just don't be afraid to stand up for yourself and just don't let it drag on and on and on too long" [Becky]

"I feel I should probably have spoken up sooner I think they [the organisation] were very supportive as soon as I raised it." [Chloe]

“... Didn't think about leaving although I probably should have but it just didn't enter my head at the time and..." [Diana]

Theme 2: The perceived role of the manager This theme addresses how each of the participants experienced the manager. What they say is based on their interpretation of comments made to them and their response to managers' behaviours.

Theme 2: The perceived role of the manager: SubTheme 1: Breached boundaries leading to loss of trust

When participants described a breach of a boundary (professional or personal) they invariably followed it up with a comment about loss of trust. There may have been a physical breach where the manager invaded the personal space of the individual or alternatively, the manager breached the boundary of the home and workplace by phoning on a day off.

Participants stated clearly in the transcripts that they did not trust their manager except for Chloe who implied that she did not trust her manager not to tell lies about her.

The manager contacted Adam on a day off when he was taking a relative to hospital and insisted that Adam take time to solve a problem.

"... I did discuss this afterwards in a meeting with him and he was blaming me for him having to phone me which I found quite insulting really... The level of trust in him as a manager... I couldn't really work with... trust had broken down." [Adam]

"I think I felt quite angry about him particular after the incident with my [relative]... I felt quite aggressive and I felt quite violated." [Adam]

“... she's just generally snappy with everyone and just causes havoc when she comes in and works in your playroom when she should really be in the office..." [Becky]

"She doesn't give clear directions and it's just kind of... you feel like she's laughing at you a lot of the time and she's just not... to me, in my personal opinion, I don't think she's a very wholesome person I can't... I can't trust her at all. I just don't think she's very genuine." [Becky] 
"... suddenly it became top priority for [W] and she stood right behind my chair and was watching over me typing, she was really in... in far too close contact with me..." [Chloe]

"I can't see myself being able to continue working with people who I didn't know what they had been told about the situation and I didn't know what had been said about me... You can't really go about asking your colleagues "has [W] said anything... what has been said about me?'” [Chloe]

"I never liked them, I never trusted them... em... I thought they were stupid in their narrow minded, ignorant way of thinking and I thought if that's the way that makes them feel better about themselves then rock on." [Diana]

"It was really, extremely uncomfortable... Really uncomfortable and it was really pushing my boundaries... because I knew I didn't have anybody to em... [pause]... back me up or step in." [Diana]

Theme 2: The perceived role of the manager: SubTheme 2: Blame and criticism

When the participants spoke about their interactions with the managers or how they perceived the manager they described how the manager often blamed them and criticised them.

"I only remember getting criticism... it was quite difficult to kind of get any conversation or any feedback from him, um... He was up to his neck in something he didn't really want to talk about it... Yet he would blame you if there were any kind of issues..." [Adam]

"Generally, he was kind of quite critical of quite a few members of the team, although not to all and very critical of external teams... He was blaming everybody except himself really." [Adam]

“... she was preparing lunches and she would ask you how to make sense of it and then she'll get all stressed and start snapping at you and make out like it's your fault that you've not organised them properly in the first place..." [Becky]

"She was hurrying me up ridiculously to go and move into another playroom and accusing me of being really late with all the children's nappies... and saying it was all my fault that I was really late." [Becky]

"I felt it was personal... Not quite attack but it was a comment that I wasn't as good as M." [Chloe]

"Em... it was different instances, there was one person who did verbally scream at me for ages and em... but it was more like catty comments like "do we like [Diana]?" and to be left... I was meant to hear that..." [Diana]
Theme 2: The perceived role of the manager: SubTheme 3: Withholding

Withholding behaviours manifested as failing to provide information or withholding praise and reward. Chloe's manager withheld rewards such as attending a fundraising dinner.

“... when we were trying to book holiday [time], all the team members were having problems getting a response. You put the request in and there was a whole procedure for doing that and we weren't getting confirmation that we had the holiday booked..." [Adam]

"There was a fundraising dinner that was organised annually... I did a lot of groundwork and she just seemed to take the credit for all that and to not involve me in the event. I think was quite a deliberate act to try and... to kind of... to delineate the lines of hierarchy pretty much." [Chloe]

“... em handovers wouldn't have been... em... for somebody else it would have been quite thorough but for me it was 'find your own way'." [Diana]

Theme 3: The perceived role of the organisation The participants seemed to view the organisation or the employer almost as a negative reflection of their experience with the manager. They described their interactions with Human Resources (HR) and the senior managers of the organisation to be unhelpful and all spoke of how they had lost trust in the organisation because of the organisational response to the bullying.

Adam described the organisation as unethical; this was not the result of malpractice but due to their apparent lack of interest in the welfare of employees and the smooth functioning of the company. Becky was the only person who filed a formal complaint about the manager. Chloe was the only one who felt the organisation were helpful when she told them her story.

"I think the organisation were kind of... Fairly unethical... but I think corporate wise the organisation as a whole probably weren't going to act on any of the things I mentioned and stuff like that so um... I think generally the organisation was quite unethical really in their dealings really." [Adam]

“... I feel quite used by them because I feel like you're just a body, just there to do the work and you don't even really get that well paid and [there's a] lot of responsibility, really high demanding, like really stressful. [It's] a really demanding job, 10 hours a day and you know you still have to put up with all this other kind of other bullying and kind of they don't really sort anything out, they just brush it under the carpet..." [Becky] 
"The organisation itself? I em... the work they do is amazing and I really enjoyed the... I learnt a lot em... but I felt I was stuck, there was no room for me to develop..." [Chloe]

“... there just wasn't a good amount of diversity and a good balance in the workplace I think that when there's a good balance of em... gender in the workplace I think it can be a little bit more harmonious... so, I think that sometimes where you get women, em... that many women in a small office... em then there can be lots of cliques and... em ... bitchiness." [Chloe]

"I think they were very cruel and I think em... it was like a class system... I was always putting my point across and sticking up for myself and when you have someone agreeing with you and then the following week they are doing the exact same thing again I began to realise that this was never going to change." [Diana]

\section{Discussion}

This IPA captured the experiences of four individuals who self-identified and were operationally identified via the amended NAR-Q as being bullied by a manager within their respective organisations. These organisations ranged from small to large private, public and voluntary sector organisations. Within the organisations, the bullying was restricted to specific teams led by a manager. Three themes and seven sub-themes were identified that reflected the feelings and thoughts of the bullied individuals.

Workplace Bullying and the need for Discount Like school bullying, workplace bullying could be described as a game played at second and thirddegree level (Berne, 1964; Bogren, 2008). According to Schiff, discounting is the mechanism by which games proceed (Schiff \& Contribs, 1975) and is an internal mechanism manifested in specific behaviours such as passive behaviours or as players (Mellor and Schiff, 1975) on the drama triangle. People discount to preserve a specific frame of reference (Schiff \& Contribs, 1975) and discount the self, others or the situation at different levels of severity, as illustrated in the discount matrix.

The common thread running through the themes were the significant levels of discounting and it is from this perspective that we propose to discuss much of the nature of bullying. We hope to demonstrate that through discounting, the participants demonstrate or display script behaviours as typified by the miniscript, leading to a sense of futility typical of a game and also a characteristic symptom of bullied individuals (Keashly, 2001; Tracy et al., 2006).

We have summarised the miniscript levels and life positions in Table 4, with illustrative quotations from the participant transcripts.

Sub -Theme 1: The impact on mental and physical health

Bullying has been documented previously as having a serious impact on the health of the individual in terms of heightened anxiety, PTSD symptoms and feelings of low self-esteem, (Matthiesen and Einarsen 2004; Nielsen et al., 2008).

The first sub-theme identified was that participants reported mental health issues because of the bullying. Adam felt depressed, Becky and Chloe both experienced anxiety (panic attacks and high levels of hyperarousal) and Diana became seriously underweight. This concurs with research data that demonstrates that exposure to workplace bullying provokes hyperarousal of the autonomic nervous system and causes feelings of anxiety (Hoel et al., 2004; Quine, 2001; Keashly and Harvey, 2006).

However, a further significant aspect of this theme is that the participants discounted the impact on their health. The participants demonstrated 'presenteeism' where they came to work in depressed and anxious states. Adam was unaware of his mood, discounted at

\begin{tabular}{|l|l|l|l|l|}
\hline Participant & I'm OK IF .... & $\begin{array}{l}\text { Stopper } \\
\text { I'm not OK, You're } \\
\text { OK }\end{array}$ & $\begin{array}{l}\text { Blamer } \\
\text { I'm OK, You're not } \\
\text { OK }\end{array}$ & $\begin{array}{l}\text { Despairer } \\
\text { I'm not OK, You're } \\
\text { not OK }\end{array}$ \\
\hline Adam & Be Strong & I feel crushed & $\begin{array}{l}\text { He [manager] was } \\
\text { out his depth }\end{array}$ & $\begin{array}{l}\text { No light at the end } \\
\text { of the tunnel }\end{array}$ \\
\hline Becky & Be Strong & I feel worthless & $\begin{array}{l}\text { She [manager] } \\
\text { doesn't give clear } \\
\text { directions }\end{array}$ & You're just a body \\
\hline Chloe & Be Strong & $\begin{array}{l}\text { I was on the lowest } \\
\text { level on the food } \\
\text { chain }\end{array}$ & $\begin{array}{l}\text { She just seemed to } \\
\text { take the credit for } \\
\text { all that }\end{array}$ & $\begin{array}{l}\text { There was no room } \\
\text { for me to develop }\end{array}$ \\
\hline Diana & Be Strong & $\begin{array}{l}\text { I was basically like } \\
\text { a nobody }\end{array}$ & $\begin{array}{l}\text { They are ignorant } \\
\text { and narrow minded }\end{array}$ & $\begin{array}{l}\text { Things are never } \\
\text { going to change }\end{array}$ \\
\hline
\end{tabular}

Table 4: Miniscript Positions 
T1, the level of existence, and stated that it was his wife who noticed that change in mood. The other participants were aware of their feelings of anxiety but discounted their impact. Chloe stated that she had panic attacks on the way to work but would continue through them and Becky stated she feels nervous all the time, but she would be in work the next day; both are discounting at T3 level as they are aware of the problem and its significance but not of there being options. Diana attributed her severe loss of weight to poor eating habits typical of medical staff, but it was her managers who noticed her weight before she did and 'backed off'. She might be discounting at T2 level as she did not account for the problem at all nor its significance.

The participants were identified as having a 'Be Strong' driver; defined by Kahler (1975) as a set of words, behaviours and gestures that reflect an internal message of I'm only OK if I am strong and don't show my feelings. This was identified in that they were not acknowledging their feelings and ignored the impact on health. Reading the transcripts, they often use the passive voice "you" rather than "I" to imply detachment (Stewart \& Joines, 2012). They believe thay are only $\mathrm{OK}$ if they can Be Strong, and this is the gateway to the miniscript.

\section{Sub-theme 2: Targets experience feelings of worthlessness}

Feelings of low self-worth are a characteristic symptom of bullying (Vie et al., 2011; Hogh et al., 2011) and personality studies have inferred that individuals who display neuroticism (a tendency to worry and ruminate) and who already have low selfesteem are more likely to experience feelings of worthlessness when bullied by others (Matthiesen and Einarsen, 2007). Becky and Diana were most explicit in their feelings of worthlessness, Becky states clearly "I believe I am worthless" with no hesitation or equivocation. Similarly, Diana stated she felt "basically like a nobody." Chloe used the expression "lowest in the food chain" and Adam described his efforts as not appreciated and he felt "crushed".

What was interesting in this analysis was that none of the participants believed they were doing a bad job. They believed they were working hard despite difficult managers, who were either struggling to cope (Adam and Becky) or were acting out of malice (Diana) or ignorance (Chloe).

If they believe they are doing a good job, why do they feel worthless? It is possible that the sense of worthlessness expressed by the participants was the result of their perceiving a psychological transaction (Berne, 1964). The managers conveyed a psychological transaction that they were either incompetent in the case of Adam or useless in the case of Becky. Adam states, "I didn't get to... get to feel I had become an incompetent worker". There is hesitation and he uses the expression "get to feel" implying that possibly the manager wanted or intended him to feel incompetent. Becky uses the expression "she makes me feel... I might as well not be there", that suggests her feeling of invisibility is the result of the manager's psychological transactions. Chloe describes a hierarchy where she is in the lowest place and her insignificance was implied by her expression "lowest on the food chain". Diana stated, "I'm thinking maybe that's what they wanted in a way ... I was always "under the foot'". The implication is that they wanted her in a one down position.

The participants are experiencing a sense of I'm not OK/You're OK and move to the Stopper position of the miniscript.

Sub-theme 3: The participants experience anger The emotion most frequently expressed by the participants was anger but what was noticeable throughout the transcripts was the use of qualifying words such as "quite", "really" and "almost" which seemed to lessen the impact of the anger. This would be a further discount of their feelings.

Adam states that he felt "quite violated" when his manager phoned him at home and he also stated "...I think the way he kind of treated people... is vile really, um... Yes, a lot anger really ... about him really." There are gaps and hesitation in the speech and the word "vile" is minimised by the word "really".

Becky is angry but she doesn't fully express her anger “... I get really annoyed at it, yeah, if I'm perfectly honest, I think". The language used subdues the anger as she speaks. She does state that she was fearful of the manager.

Chloe did lose her temper with her manager but the manager's behaviour was considered "appalling" by a colleague. Diana uses the word "frustrated" and there is gallows laughter.

The reader may perceive unexpressed anger in other quotes as well. The participants were angry but they did not fully express the anger although the researcher was able to hear the anger and tension in the voice.

When we consider how the internal process of discounting is manifested externally as passive behaviours (Mellor \& Schiff, 1975), such behaviours were observed with the participants. The lack of action on their parts may be seen as doing nothing and is discussed in sub-theme 4.

Becky and Chloe over-adapted to the manager by working faster and harder and Diana stated explicitly (not quoted) that she adapted to the organisation; 
when they backed off after her weight loss she had some respite but she stated later that she survived by "adapting".

The panic attacks may be construed as agitation. There was no evidence of Incapacitation such as being absent due to illness but there were some instances of violence in the form of Chloe's aggression when she lost her temper.

Sub-theme 4: "Nipping it in the bud"

All the participants stated that in retrospect they wished they had acted sooner, Becky used the euphemism "nipping it in the bud".

Adam left the organisation without making a complaint, saying he felt he did not have the mental energy at the time to pursue a formal complaint which suggests the passive response of doing nothing.

Becky was pursuing a complaint at the time of interview but it was a potentially flawed process (i.e. the manager was conducting the investigation) and at time of writing had failed to reach a resolution.

Chloe made a complaint coincident with the manager being made redundant because of organisational changes. She noted that she let the situation continue as she had other personal issues that preoccupied her thinking and although her situation was bad it was better than being unemployed.

Diana never considered leaving and stated that she adapted to the situation in the early years, then left 5 years later with no acknowledgement (gift or card) from colleagues.

When the targets are enmeshed in a bullying dynamic it is very difficult to take action because of the high level of discounting and the passivity it creates. This passivity is a common symptom experienced by many targets (Shickerwath and Zapf, 2011) where agency and autonomy are lost. The loss of confidence and self-esteem leaves the individual drained of resources; these are the very traits needed to cope with the stress of the constant negative interaction (Keashly, 2001).

Once individuals receive help, e.g. through coaching or counselling they feel better equipped to seek redress. They are also able to see their role in the process in a healthier and more responsive way (Shickerwath and Zapf, 2011; Tehrani, 2012).

Theme 2: The perceived role of the manager The second superordinate theme was how the manager was perceived by the participants; and it was sub-divided into three themes. The managers were perceived as critical and blaming, as withholding, and as breaching the boundaries of their employees. We believe these negative perceptions are the result of the managers discounting the participants and them- selves. Similar perceptions have been noted before specifically feelings of being discounted, withholding criticism and blaming (Keashly, 2001). We do not have the managers' sides of the story and so this analysis focuses on the participants' perceptions of discounts by the manager that reinforce the feelings and beliefs of the participants.

\section{Sub-theme 1: Breaching boundaries leading to loss of trust:}

The participants felt they could no longer trust their manager and said so; this loss of trust was also applied to the organisation if they failed to act in favour of the participants. From a TA perspective, the loss of trust would suggest that the manager is no longer perceived as OK. They are perceived as interfering (Adam), not wholesome, (Becky), untruthful (Chloe) and ignorant and narrow minded (Diana).

The managers breached the boundaries of their employees; sometimes the breach was in the personal space as described by Chloe where the manager stood over her chair and spoke aggressively. Often the breach was subtler e.g. phoning Adam on a day when he was taking a relative to hospital. This lack of respect for the boundary seems to contribute to the loss of trust mentioned earlier. Adam uses the word "violated" but qualifies it with "quite". It resulted in a loss of trust for him.

Becky see her manager as untrustworthy and as causing havoc, Diana describes her managers and colleagues as narrow minded and she feels unsafe because she has "nobody to back me up"

According to Social Exchange Theory (SET) studies (Parzefall \& Salin, 2010) loss of trust can be traced back to a perceived breach of the organisation's psychological contract at an implicit level. In such instances, employees will re-evaluate their relationship with the organisation more negatively and adjust behaviour accordingly. . They reassess their view of the world as an unsafe place (Lutgen-Sandvik, 2013). From a TA perspective, when the boundary is breached the participants experience a threat to their sense of autonomy and as such are more likely to engage in games and to resort to script behaviour, thus reinforcing the miniscript process.

\section{Sub-theme 2: Blame and Criticism}

All the participants experienced criticism either of their work (Adam and Becky) or at a personal level (Chloe and Diana).

Adam states that his manager was "very, very critical" (emphasised by repeating the word 'very') which indicates that this was a chronic, relentless problem (Tracy et al., 2006). Becky stated her manager blamed her for not being quick enough. Chloe felt criticised for not being as good as a colleague. Diana was verbally 
abused and was subject to "catty [spiteful] comments". We do not know the exact words of the managers but what is crucial is the participants felt criticised and blamed and these negative perceptions are important in driving the dynamic (Crawshaw, 2007).

The act of blaming involves a discount; the individual doing the blaming is not accounting for their role in the interaction and it is typical of the Persecutor position on the drama triangle (Boyce, 2012). When the participants described their manager as blaming there is an implied transaction that the manager was discounting their own behaviour e.g. Becky states her manager gets muddled when preparing lunches and “... makes out like it's your fault that you've not organised them properly in the first place". She is describing the switch in the game where the manager switches from Victim where she feels muddled to Persecutor where she blames Becky (Karpman, 1968).

Similarly, Adam described his manager as critical of others and trying to lay the blame on "everyone but himself', the manager is in the position of Persecutor and Adam is in the Victim position.

Games involve a discount and are played to exchange specific types of strokes (Berne,1964; Boyce, 2012; Steiner, 1974) and it appears that in these situations there were a lack of positive strokes and a lot of negative strokes that were either explicit, as when Adam and Diana state that the managers would make specific derogatory remarks), or implicit where Chloe felt it was implied that "I wasn't as good as M".

The withholding of positive strokes and the giving of negative strokes by the manager may explain the feelings of worthlessness already discussed (McKenna, 1974). The manager is also perceived as being in the one up position (I'm OK, You're not OK) and this would invite a feeling of I'm not OK, You're OK being experienced by the participants (Ernst, 1971).

Interestingly, as mentioned earlier, there is no evidence of self-blame, a common strategy which can sometimes help maintain the dynamic as the targets of bullying will blame themselves as a way of maintaining a status quo (Hogh et al., 2011; Keashly and Harvey, 2006). None of the participants saw themselves as to blame for the situations they described but rather they believed the manager was avoiding responsibility and they would offer a rationalisation of the managers' behaviour to make sense of the experience; this would be the Blamer position of the miniscript.

\section{Sub-theme 3: Withholding}

The perceived withholding behaviours of the managers, be it information regarding holidays (Adam) or praise (Becky) or reward (Chloe and Diana) are further examples of a perverse stroke economy, where positive strokes are withheld (McKenna, 1974). The manager may refuse to give positive strokes, possibly as a power play. The manager has the power to endow praise and reward (Krausz, 1986) but withholds it as a way of maintaining the power differential. Rewards could be withdrawn capriciously as in the case of Chloe who was not allowed to attend a special event or Diana who received no acknowledgement when leaving the organisation.

Theme 3: The perceived role of the organisation When describing their respective organisations three of the participants described their organisation as a reflection of their experience with the manager. For Adam, the organisation was unethical in that they tacitly permitted the bullying by being intransigent and uncaring, he states that they "weren't going to act on the things I said". Similarly, Becky saw her organisation as colluding with the bully; they too, were uncaring, "you are just a body" and she believed that when she filed her complaint they would "brush it under the carpet".

Chloe viewed her organisation favourably, they made the manager redundant because of structural changes and the fact that they were a charity may have softened her attitude; "... the work they do is amazing" but she also said there was "... no room for me to develop". She thought their lack of diversity (having too many middle-aged white women) facilitated the bullying dynamic.

Diana saw the hospital as colluding in the bullying as they allowed it to go unchallenged almost as rite of passage; things were "never going to change". There is a wealth of evidence that nursing seems to have a high incidence of bullying (Francis, 2015) which may be attributed to the hierarchical nature of the medical profession where predatory alliances are maintained and bullies are rewarded by promotion (Hutchinson et al, 2010).

In this final theme, the Despairer position of the miniscript is manifest where the participants see the situation as futile and hopeless, there is a sense of I'm not OK and You're not OK. The process seems to provoke a move to script in the participants and perhaps the perceived lack of interest or the perceived collusion by the organisation is the final straw leading to the feelings of futility and despair.

Across all transcripts, with every theme, it is noticeable that the participants provided a narrative populated with words that diminished their experience and muted their emotions. There was hesitation, confused syntax and mixed up tenses (present and past). This is an indication of the confusion and the struggle that bullied individuals go through to make sense of their experience (Tracy et al., 2006).

Chloe and Diana stated that the bullying they experienced was subtle and hard to describe and so 
articulating their experience was difficult, (not quoted), many bullied people describe subtle interactions that are difficult to verbalise (Keashly, 2001; Soares, 2012). However, this lack of coherent narrative illustrates the impact of workplace bullying on individuals. The transactions that comprise bullying are at the psychological level and therefore may be hard to identify or verbalise.

Does this mean that the bullying experience is a reenactment from the participants' pasts? While some researchers argue that people who are bullied should be treated solely in relation to their current experience (Namie, 2017) others suggest that responses to bullying are a re-enactment of the past (Keashly, 2001; Tehrani, 2012) and so the participants may be reexperiencing these feelings of worthlessness as part of their script process. However, Nielsen et al. (2008) makes the point that even for individuals with a strong sense of coherence, where an individual has an internal sense of optimism, confidence and control over their situation, (Antonovsky, 1987 referenced in Nielsen et al 2008), bullying can leave the individual feeling traumatised and powerless. We propose that individuals who are bullied react to the aggressor using script behaviours rather than acting from an Adult, autonomous position.

It must be emphasised that these collections of data are based on the experiences and perceptions of four individuals and we do not have the other side of the story. One could argue that the managers were making legitimate requests and the participants were interpreting this in a negative way, perhaps hearing criticism where none was intended. This is the problem when trying to resolve a conflict at an organisational level, where parties get caught in a 'he said - she said' dyad (Crawshaw, 2017).

It is perhaps the prolonged and sustained nature of the interactions that would suggest that this was more than a misunderstanding (Leymann, 1996, Einarsen et al., 2009). Here, the participants were experiencing a minimum of five negative acts weekly/daily over a prolonged period; 9 months (Adam) to eight years (Diana). The participants may have been unable to assert themselves thereby prolonging the situation (Mountain \& Davidson, 2011); there is evidence that they tried to speak to their managers and these challenges were not effective, as the issues went on for a substantial time until the participants either left (Adam and Diana) or made a complaint (Becky and Chloe).

There is little known about the motivation and experience of the perpetrators; they might be acting out of maliciousness (Keashly, 2001; Namie, 2017) or interpersonal ineptitude (Crawshaw, 2007). The research literature acknowledges this deficit with little written about the motivations of the perpetrators (Samnani \& Singh, 2012). It is mainly the research of Crawshaw (2007) who has evidenced that abrasive managers lack empathy and often see their behaviour as either acceptable or necessary. They respond to threat with aggression and they lack awareness of the impact of their behaviour. This correlates with the assertion of Mountain and Davidson (2011), where they describe a bully as someone who is scared and responds to threat with a substitute feeling of anger and adopts a critical management style and therefore responds from a script position.

The participants imply that their organisation condones bullying and is ambivalent in its desire to eliminate it. We do not know for a fact if that is true what organisation will openly admit to an abusive culture? They may wish to be perceived as tough and therefore a harsh management style would be considered an effective way to improve performance (Wheeler et al., 2010; Samnani \& Singh, 2012). Such an approach has been shown to be counter-productive as bullying breaches the implicit contract between employee and employer resulting in the loss of trust and causing the employee to withdraw goodwill from the employer (Parzefall \& Salin, 2010). It is also possible that organisations feel unable to effectively confront an abrasive manager and therefore do nothing for fear of making it worse (Crawshaw, 2007).

\section{Limitations and future research}

This was a small-scale study focusing on the experience of only 4 people; while this is an acceptable sample size for IPA (Hefferon \& Gil-Rodriguez, 2017), other IPA studies on this topic have used larger sample sizes (Farrell et al., 2014). However, the experiences of our participants do concur with other qualitative studies (Keashly, 2001; Tracy et al., 2006) although there was some evidence of difference, e.g. the lack of self-blame was unusual and unexpected and with the small sample may not be representative.

We kept the questions as open as possible to let the experiences be heard so there is a risk that the data is not fully corroborated because we only have the participants' perspectives and we do not know for certain that there was not confused or misunderstood communication. It may have been pertinent to ask more probing questions about how the manager might have described the situation or how might the participant have contributed to the process.

Perhaps our approach as counsellors/ psychotherapists has an impact on the interview process, where we may have focused on minimising distress; this could be considered for further research work of this nature. We may also have tended to be biased in favour of participants who were also perceived as counselling clients, even if not our own. 
We have not considered the role and possible impact of bystanders as to do so would have made this piece of research more complex and lengthy. The role of the bystander is extremely important in games (Clarkson, 1993) and in the bullying dynamic bystanders may facilitate the manager explicitly or by their silence or may be seen as colluding, (Niven, 2017). A further IPA is planned to look at the role of the bystander and how might their experience be utilised to help organisations prevent bullying from taking place.

We are also unable to state if there is any evidence of their bullying situation being a re-enactment from the past. The nature of the questions was such that they stimulated the participant to discuss their recent bullying situation rather than looking at past experiences; this might be followed up through more research.

To more fully understand script processes and the extent of discounting, it would be pertinent to examine the experience of the bullied individual through case study research. There are very few accounts of target experience as a case study, and this might be more effectively explored using Hermeneutic Single-Case Efficacy Design (HSCED) method (Elliot, Partyka, Alperin, Dobrenski, Wagner, Messer, Watson \& Castonguay, 2009).

\section{Conclusion}

We conclude that for the those impacted by bullying, their feelings of anger and worthlessness, their loss of trust, and the symptoms of depression and anxiety are the result of their feelings of being discounted by their managers and their organisations. The managers appear to discount the participants through a diet of negative strokes and the withholding of positive strokes. The breach of boundaries by the manager is a discount of the participants' autonomy and as the transactions accumulate over time, the victims begin to discount their fear and anger and their health starts to suffer. To maintain a sense of OKness they ignore their symptoms of low mood and anxiety and display passive behaviours such as doing nothing and overadaptation, neither of which are effective (LutgenSandvik, 2013).

The process is exacerbated by the organisations' apparent discounts of the experiences of its employees; failing to act effectively gives the appearance of condoning bullying. In the eyes of the participants the organisations show scant regard for their plight, to which they respond through script behaviours.

We only have the perspective of the participants but it might be assumed that their managers are also reacting from a position of threat (Crawshaw, 2007). Being in script prevents autonomy and agency and thus prevents authentic interactions that would be creative and productive for all parties.

Bullying is an insidious problem that seriously impacts the mental and physical heath of those affected; it has no place in the modern workplace, yet it persists. It is facile to view it simply as a conflict between a target and perpetrator but rather it reflects an organisation and its culture. To paraphrase Pamela Lutgen-Sandvik (2003), workplace abuse will continue until there is reform of the workplace, according to a new social contract which encourages cooperation, justice and community.

Mary O'Neill PhD MSc in TA Counselling is a BACP accredited counsellor and an EMDR accredited practitioner. She can be contacted at oneill.mary3606@gmail.com.

Denise Borland PhD MSc is a Certified Transactional Analyst (Psychotherapy) and UKCP Psychotherapist who specialises in trauma recovery and vocal and psychological coaching. She can be contacted at denise@noblehouse.scot

\section{References}

ACAS (2015) Bullying and Harassment at Work: Guidance for Managers and Employers. August 2017] www.acas.org.uk/publications Accessed 5 August 2017

Antonovsky, A. (1987) Unraveling the mystery of health: How people manage stress and stay well. San Francisco:Jossey-Bass

Berne, E. (1961) Transactional Analysis in Psychotherapy. New York: Grove Press.

Berne, E. (1964) Games People Play. New York: Penguin Press

Bogren, N.G. (2008) Using Transactional Analysis to Understand and Heal the Effects of Bullying in Children, Transactional Analysis Journal, 38:4 335-342

Boyce, G. (2012) No More Drama: A Practical Guide to Healthy Relationships Los Gatos, CA: Soul Dance Query at Smashwords.com

Branch, S., Ramsay, S., \& Barker, M. (2012) Workplace bullying, mobbing and general harassment: A review, International Journal of Management Reviews, 15 (3) 280 99

Clarkson, P. (1993) Bystander Games, Transactional Analysis Journal, 23:3 158-172

Cornell, W.F., de Graaf, A., Newton, T. \& Thunnissen, M. (2016) Into TA: A Comprehensive Textbook on Transactional Analysis London: Karnac Books Ltd.

Crawshaw, L. (2007) Taming the Abrasive Manager: How to End Unnecessary Roughness in the Workplace, San Francisco: Jossey-Bass 
Crawshaw, L. (2017) Rethinking "the Bully" in Bullying. Unpublished data presented at International Association for Workplace Bullying and Harassment Summer School, University of Huddersfield, July

Einarsen, S (2017) personal communication

Einarsen S. \& Raknes, B.I. (1997) Harassment in the Workplace and the Victimization of Men, Violence and Victims, 12 (3) 247-63

Einarsen, S., Aasland, M.S. \& Skogstad, A. (2007) Destructive leadership behaviour: a definition and conceptual model, The Leadership Quarterly, 18 (3) 207-16

Einarsen, S., Hoel, H., \& Notelaars, G. (2009) Measuring exposure to bullying and harassment at work: Validity, factor structure and psychometric properties of the Negative Acts Questionnaire-Revised, Work \& Stress, 23 (1) 24-44

Einarsen, S., Hoel, H., Zapf D. \& Cooper, C. (2011) Bullying and Harassment in The Workplace; Developments in Theory Research and Practice $2^{\text {nd }} E d$. London: CRC Press

Elliot, R., Partyka, R., Alperin, R., Dobrenski, R., Wagner, J., Messer, S.B., Watson, J.C. \& Castonguay, L.G. (2009) An Adjudicated Hermeneutic Single-Case Efficacy Design Study of Experiential Therapy for Panic/Phobia, Psychotherapy Research Methods, 19 (4-5) 543

Ernst, F. H. (1971) The OK Corral: The Grid for Get-OnWith, Transactional Analysis Journal, 1 (4), 231-40

Farrell, D., Keenan, P. \& Knibbs, L. (2014) An Interpretative Phenomenological Analysis (IPA) of EMDR Clinicians Experiences of Bullying. Social Sciences Directory, 3(1) 3155

Francis, R.F. (2015) Report: Freedom to Speak Up - An Independent Review into Creating an Open and Honest reporting Culture in the NHS

http://freedomtospeakup.org.uk/wp-

content/uploads/2014/07/F2SU web.pdf Accessed 29 May 2018

Glasø, L., Matthiessen, S.B., Nielsen, M.B., \& Einarsen, S. (2007) Do Targets of Workplace Bullying Portray a General Victim Personality Profile?, Scandinavian Journal of Psychology, 48 (4) 313-9

Glendinning, P.M. (2001) Workplace Bullying: Curing the Cancer of the American workplace, Public Personnel Management, 30 (3) 269-86

Harvey, M., Treadway, D., Heames, J.T., \& Duke, A. (2009) Bullying in the 21st Century Global Organization: An Ethical Perspective. Journal of Business Ethics, 85: 1 27-40

Hefferon, K. \& Gil-Rodriguez, E. (2017) Interpretative Phenomenological Analysis

https://thepsychologist.bps.org.uk/volume-24/edition10/methods-interpretative-phenomenological-analysis Accessed 15 February 2016
Hoel, H., Faragher, B. \& Cooper, C.L. (2004) Bullying is detrimental to health, but all bullying behaviours are not necessarily equally damaging, British Journal of Guidance \& Counselling, 32 (3) 367-87

Hogh, A., Hoel, H., \& Carneiro, I.G. (2011) Bullying and Employee Turnover Among Healthcare Workers: A ThreeWave Prospective Study. Journal of Nursing Management, 19: $6742-751$

Hutchinson, M., Vickers, M.H., Wilkes, L. \& Jackson, D. (2010) A Typology of Bullying Behaviours: The Experiences of Australian Nurses, Journal of Clinical Nursing, 19 (15-16) 23 19-28

Joines, V. (1982) Similarities and Differences in Rackets and Games, Transactional Analysis Journal, 12:4 280-283

Kahler, T. (1975) Drivers: The Key to the Process of Scripts Transactional Analysis Journal 5:3 280-284

Kahler T \& Capers, H (1974) The miniscript Transactional Analysis Journal, 4:1 26-42

Karpman, S. (1968) Fairy Tales and The Script Drama Triangle. Transactional Analysis Bulletin, 7:26 39-46

Keashly, L. (2001) Interpersonal and Systemic Aspects of Emotional Abuse at Work: The Target's Perspective. Violence and Victims, 16: 3 233-268

Keashly, L. \& Harvey M. (2006) Workplace Emotional Abuse, in Kelloway, E. K., Barling, J. \& Hurrell, J. J., Ed. Handbook of Workplace Violence. London: Sage Publications Inc.

Krausz, R. (1986) Power and Leadership in Organizations, Transactional Analysis Journal, 16:2 85-94

Levine, P. (1997) Waking the tiger: Healing trauma. Berkeley: North Atlantic Books.

Leymann, H. (1996) The Content and Development of Mobbing at Work. European Journal of Work and Organizational Psychology, 5: 2 165-184

Lutgen-Sandvik, P. (2003) The Communicative Cycle of Employee Emotional Abuse: Generation and Regeneration of Workplace Mistreatment. Management Communication Quarterly, 16:4 471-501

Lutgen-Sandvik, P. (2013) Adult Bullying - A Nasty Piece of Work: Translating a decade of Research on Non-Sexual Harassment, Psychological Terror, Mobbing and Emotional Abuse on the Job. Pennsylvania: ORCM Academic Press

Matthiesen, S.B. \& Einarsen, S. (2004) Psychiatric Distress and Symptoms of PTSD Among Victims of Bullying at Work. British Journal of Guidance \& Counselling, 32 (3) 335-356.

Matthiesen, S.B. \& Einarsen, S. (2007) Perpetrators and Targets of Bullying at Work: Role Stress and Individual Differences. Violence and Victims, 22 (6) 735-753

McKenna, J. (1974) Stroking Profile: Application to Script Analysis. Transactional Analysis Journal, 4:4 164-168 
McLeod, J. (2011) Qualitative Research in Counselling and Psychotherapy ( $2^{\text {nd }}$ Ed. $)$. London: Sage

Mellor, K., \& Schiff, E. (1975) Discounting. Transactional Analysis Journal, 5:3 295-302

Mountain, A. and Davidson, D. (2011) Working Together: Organisational Transactional Analysis and Business Performance. Farnham, Surrey: Gower Publishing.

Namie, G. (2017) The WBI Guide to Selecting a Therapist Seattle: Workplace Bullying Institute www.workplacebullying.org/individuals/solutions/selecting-atherapist/ Accessed 16 September 2017

Nielsen, M. B., Matthiessen, S. B. \& Einarsen, S. (2008) Sense of Coherence as a Protective Mechanism Among Targets of Workplace Bullying. Journal of Occupational Health Psychology, 13(2) 128-136

Nielsen, M.B., Notelaers, G. \& Einarsen, S. (2011) Measuring Exposure to Workplace Bullying. In S. Einarsen, H. Hoel, D. Zapf And C. Cooper (Eds), Bullying and Harassment in The Workplace; Developments in Theory Research and Practice 2nd Ed. 397-421. London: CRC Press

Niven, K. (2017) Rethinking 'the bully' in bullying: Third party witnesses as bullies-by-proxy? Unpublished data presented at International Association for Workplace Bullying and Harassment Summer School, University of Huddersfield, July

Notelaers, G. \& Einarsen, S. (2013) The world turns at 33 and 45: Defining simple cut off scores for the Negative Acts Questionnaire-Revised in a representative sample. European Journal of Work and Organisational Psychology, 22 (6) 670-82

Parzefall, M.R. \& Salin, D. M. (2010) Perceptions of and Reactions to Workplace Bullying: A Social Exchange Perspective. Human Relations, 63 (6) 761-780

Pietkiewicz, I. \& Smith, J.A. (2012) A Practical Guide to Using Interpretative Phenomenological Analysis in Qualitative Research Psychology. Psychological Journal, 20 (1) 7-14

Quine, L. (2001) Workplace Bullying in Nurses. Journal of Health Psychology, 6 (1) 73-84

Rothschild, B. (2000) The Body Remembers. New York: W. W. Norton \& Co.

Samnani, A. \& Singh, P. (2012) 20 Years of Workplace Bullying Research: A Review of The Antecedents and Consequences of Bullying in The Workplace. Aggression and Violent Behaviour, 17 (6) 581-589

Schiff J \& Contributors (1975) The Cathexis Reader: Transactional Analysis Treatment of Psychosis. New York, Harper and Row

Schiff, A.W \& Schiff, J.L. (1971) Passivity. Transactional Analysis Journal, 1:1 71-78
Shickerwath, J. \& Zapf, D. (2011) Inpatient Treatment of Bullying Victims. In S. Einarsen, H. Hoel, D. Zapf And C. Cooper (Eds.), Bullying and Harassment in The Workplace; Developments in Theory Research and Practice 2nd Ed. London: CRC Press 397-421

Smith, J.A., Flowers, P. \& Larkin, M. (2009) Interpretative Phenomenological Analysis: Theory, Method and Research. London: Sage

Soares, A. (2012) When Darkness Comes: Workplace Bullying and Suicidal Ideation, In Tehrani, N., (Editor) Workplace Bullying: Symptoms and Solutions. Hove. Routledge, 67-80

Steiner, C. (1974) Scripts People Live $2^{\text {nd }}$ Ed. New York Grove Press.

Stewart, I. \& Joines, V. (2012) TA Today, A New Introduction to Transactional Analysis, $2^{\text {nd }}$ edn Nottingham: Lifespace

Tehrani, N. (2004) Bullying: A Source of Chronic Post Traumatic Stress? British Journal of Guidance \& Counselling, 32:3 357-366

Tehrani, N. (2012) An Integrated Counselling Approach. In Tehrani, N., (Ed) Workplace Bullying: Symptoms and Solutions. Hove: Routledge 149-165

Tracy, S.J., Lutgen-Sandvik, P.\& Alberts, J.K. (2006) Nightmares, Demons and Slaves: Exploring the Powerful Metaphors of Workplace Bullying. Management Communication Quarterly, 20 (2) 148-185

Trades Union Congress (2015) Nearly a third of people are bullied at work, says TUC

https://www.tuc.org.uk/news/nearly-third-people-are-bulliedwork-says-tuc Accessed 5 January 2018

Vartia, M. (2001) Consequences of Workplace Bullying with Respect to the Wellbeing of its Targets and the Observers of Bullying, Scandinavian Journal of Work and Environmental Health, 27 (1) 63-69

Vartia, M. \& Tehrani, N. (2012) Addressing Bullying in The Workplace. In Tehrani, N. (Ed), Workplace Bullying: Symptoms and Solutions. Hove. Routledge 213-229

Vie, T.L., Glasø, L. \& Einarsen, S. (2011) Health Outcomes and Self-Labelling as A Victim of Workplace Bullying. Journal of Psychosomatic Research, 70 (1) 37-43

Wheeler, A.R., Halbesleben, J.R.B. \& Shanine, K. (2010) Eating Their Cake And Everyone Else's Cake, Too: Resources as The Main Ingredient to Workplace Bullying, Business Horizons, 53 (6) 553-560

Zapf, D. \& Einarsen, S. (2011) Individual Antecedents of Bullying: Victims and Perpetrators. In S. Einarsen, H. Hoel, D. Zapf And C. Cooper (Eds), Bullying and Harassment in The Workplace; Developments in Theory Research and Practice $2^{\text {nd }} E d$. London: CRC Press 


\section{Appendix 1: Negative Acts Questionnaire (Adapted from Einarsen et al., 2009)}

\begin{tabular}{|c|c|c|c|c|c|c|}
\hline 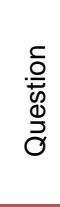 & In the past 6 Months have you experienced any of the following & $\frac{\bar{d}}{\grave{D}}$ & 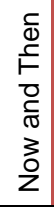 & 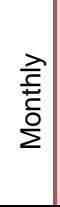 & $\begin{array}{l}\frac{\lambda}{d} \\
\frac{\mathbb{d}}{3}\end{array}$ & 름 \\
\hline 1 & Someone withholding information which affects your performance & & & & & \\
\hline 2 & Being ridiculed or humiliated in connection with your work & & & & & \\
\hline 3 & Being ordered to do work below your level of competence & & & & & \\
\hline 4 & $\begin{array}{l}\text { Having key areas of responsibility removed or replaced with more trivial } \\
\text { or unpleasant tasks }\end{array}$ & & & & & \\
\hline 5 & Spreading gossip or rumours about you & & & & & \\
\hline 6 & Being ignored or excluded & & & & & \\
\hline 7 & $\begin{array}{l}\text { Having insulting or offensive remarks made about your person, attitudes } \\
\text { or your private life }\end{array}$ & & & & & \\
\hline 8 & Being shouted at or being the target of spontaneous anger & & & & & \\
\hline 9 & $\begin{array}{l}\text { Intimidating behaviours such as finger-pointing, invasion of personal } \\
\text { space, shoving, or blocking your way }\end{array}$ & & & & & \\
\hline 10 & Hints or signals from others that you should quit your job & & & & & \\
\hline 11 & Repeated reminders of your errors or mistakes & & & & & \\
\hline 12 & Being ignored or faced with a hostile reaction when you approach & & & & & \\
\hline 13 & Persistent criticism of your errors or mistakes & & & & & \\
\hline 14 & Having your opinions ignored & & & & & \\
\hline 15 & Practical jokes carried out by persons you don't get along with & & & & & \\
\hline 16 & Being given tasks with unreasonable deadlines & & & & & \\
\hline 17 & Having allegations made against you & & & & & \\
\hline 18 & Excessive monitoring of your work & & & & & \\
\hline 19 & $\begin{array}{l}\text { Pressure not to claim something to which you are by rights entitled } \\
\text { (holiday entitlement, sick pay, travel expenses) }\end{array}$ & & & & & \\
\hline 20 & Being the subject of excessive teasing or sarcasm & & & & & \\
\hline 21 & Being exposed to an unmanageable workload & & & & & \\
\hline 22 & Threats of violence, or physical abuse or actual abuse & & & & & \\
\hline
\end{tabular}

Note: This questionnaire is adapted from the Negative Acts Questionnaire (Einarsen, Hoel\& Notelaers, 2009; Notelaers \& Einarsen, 2013)

Permission was granted to use this adapted version by Einarsen (2017)

Anyone wishing to use the NAQ should first read the information and follow the conditions of use at http://www.uib.no/en/rg/bbrg/44045/naq 


\section{Appendix 2: Questionnaire}

This questionnaire is divided into two sections; Part 1 is general data relating to your personal details and your workplace role. Details from this section will be heavily censored to ensure anonymity. Part 2 is specific questions relating to your experience with the organisation where you experienced conflict. Please be assured that every effort will be made to preserve confidentiality.

Part 1: Please complete and tick where appropriate.

First Name:

Age:

Occupation:

Type of Organisation:

\begin{tabular}{|l|l|l|l|l|l|}
\hline Public sector & & Private sector & & Voluntary Sector & \\
\hline
\end{tabular}

Size of organisation:

\begin{tabular}{|l|l|l|l|l|l|}
\hline $\begin{array}{l}\text { More than } 1,000 \\
\text { employees }\end{array}$ & $100-1,000$ employees & & Less than 100 Employees \\
\hline
\end{tabular}

Number of individuals in your team:

How long have you worked with this organisation?

Do you have any management responsibility?

Describe your current status with this organisation

\begin{tabular}{|l|l|}
\hline I no longer work for this organisation & \\
\hline I am currently off ill (relating to my situation) & \\
\hline I am currently employed by the organisation in another position & \\
\hline I am currently working in the team & \\
\hline
\end{tabular}


Part 2 Definition of Bullying

Bullying in the workplace can be defined as "a situation where one or several individuals, persistently over a period of time, perceive themselves to be on the receiving end of negative actions from one or several persons, in a situation where the target of bullying has difficulty in defending him or herself against these actions"

Using this definition would you consider yourself to have been the subject of workplace bullying? Yes or No (please circle)

$2 \quad$ How long have you been facing a hostile situation (to the nearest month)? If you are no longer with the organisation, how many months did you face the hostile situation until you left?

3

Are you still facing these situations?

Yes, it is still happening

Not now and I am still in the same job

Not now as the bully has been moved on

Not now as I am no longer with the organisation

4

In the period mentioned who was against you

Co-worker

Manager or superior

5

How many people were against you in this period

6

Was the main perpetrator male or female

7

Did you have someone to turn to about these problems (tick all that apply)

\begin{tabular}{|l|l|}
\hline & \\
\hline Yes & \\
\hline Colleague & \\
\hline HR & \\
\hline Counselling through EAP & \\
\hline Union representative & \\
\hline Other manager & \\
\hline GP & \\
\hline Psychologist & \\
\hline Lawyer & \\
\hline Friends outside the workplace & \\
\hline Family members & \\
\hline No & \\
\hline I have no-one to whom I could turn; and I wish I had & \\
\hline I have no-one to whom I could turn; and I did not need anyone & \\
\hline
\end{tabular}

